\title{
PENGENALAN ANGKA KEPADA ANAK USIA 6 TAHUN DENGAN MEDIA KARTU
}

\author{
Geraisa Dayura Chanet ${ }^{1}$ Adnani Budi Utami ${ }^{2}$ \\ Email : geraisa13@gmail.com ${ }^{1}$ \\ Universitas 17 Agustus 1945 Surabaya Jawa Timur, Indonesia ${ }^{1,2}$
}

\begin{abstract}
The purpose of this study was to determine the causes of 6 year old children having difficulty recognizing basic numbers and how to overcome them. The method in this study used a qualitative research design with a single case experience design with the provision of intervention, namely number recognition using card media and mentoring. The intervention was carried out at the subject's house for 1 hour for 6 meetings. The results obtained during the 6 meetings the subject was able to recognize the number symbols 1-10 but for the symbols of dozens of subjects still tended to be mispronounced and the subjects needed concentration to be able to remember. The conclusion of this study is that the subject can more quickly recognize numbers with the help of media in their learning activities so that subjects can learn happily and do not feel difficult.

Key words: Development Stage; Early Childhood; Difficulty Learning; Difficulty Recognizing Numbers
\end{abstract}

\section{Abstrak}

Tujuan dari penelitian ini adalah untuk mengetahui penyebab anak usia 6 tahun sulit mengenal angka-angka dasar dan bagaimana cara mengatasinya. Metode dalam penelitian ini menggunakan desain penelitian kualitatif dengan desain kasus tunggal (single case experiement) dengan pemberian intervensi yaitu pengenalan angka dengan media kartu dan pendampingan. Pelaksanaan intervensi dilakukan di rumah subjek selama 1 jam sebanyak 6 kali pertemuan. Hasil yang diperoleh selama 6 kali pertemuan subjek dapat mengenal simbol angka 1-10 namun untuk simbol belasan subjek masih cenderung salah penyebutannya dan subjek mebutuhkan konsentrasi untuk dapat mengingat. Kesimpulan dari penelitian ini adalah subjek dapat lebih cepat mengenal angka dengan bantuan media dalam kegiatan belajarnya sehingga subjek dapat belajar dengan senang dan tidak merasa kesulitan.

Kata kunci: Tahap Perkembangan; Anak Usia Dini; Kesulitan Belajar; Kesulitan Mengenal Angka

\section{PENDAHULUAN}

Proses perubahan perilaku dari tidak matang menjadi matang merupakan suatu perkembangan pada anak. Anak akan belajat menguasai suatu tingkatantingkatan yang lebih tinggi dari aspekaspek gerakan, berpikir dan interaksi baik dengan orang lain atau dengan benda-beda yang ada didalam lingkungannya. Dalam hal pendidikan, bagi anak usia 4- 6 tahun secara formal dapat ditempuh di taman kanak-kanak. Taman kanak-kanak merupakan suatu lembaga yang ditunjukkan untuk melaksanakan suatu proses pembelajaran agar anak dapat mengembangkan potensi yang ada didalam dirinya sejak dini. Proses pembelajaran sejak usia dini dapat membantu kesiapan anak untuk memasuki jenjang pendidikan yang lebih lanjut. Anak juga mendapat stimulasi fisikmotorik, kognitif, sosial dan emosi sesuai tingkat usianya.

Mendidik anak usia dini perlu pemahaman tentang dunia anak, bagaimana proses perkembangan anak, apa saja aspek-aspek yang mendukung perkembangan anak. Diharapkan para 
pendidik memiliki pemahaman tentang hal-hal tersebut dan dapat membina anak usia dini dengan baik.

Belajar adalah suatu proses dan bukan suatu hasil, karena itu belajar berlangsung secara aktif dan integratif dengan menggunakan berbagai bentuk perbuatan untuk mencapai tujuan (Soemanto, dalam Ahyani \& Raharjo, 2011). Belajar tentunya tidak hanya bersifat fisik, tetapi juga melibatkan mental. Anak-anak yang melakukan kegiatan belajar harus siap secara mental, agar proses pembelajaran dapat berlangsung dengan baik.

Aktifitas belajar tidak selamanya berlangsung dengan baik. Pada anak usia dini aktifitas belajar kadang lancar, kadang tidak, kadang cepat memahami apa yang telah diajari, kadang juga terasa sulit. Setiap anak berbeda-beda. Perbedaan inilah yang menyebabkan tingkah laku yang berbeda pada anak didik. Siswa yang tidak dapat belajar sebagaimana mestinya itulah yang disebut dengan kesulitan belajar.

$$
\text { Menurut Jamaris }
$$

menyatakan, "Kesulitan belajar tidak berhubungan langsung dengan tingkat inteligensi dari individu yang mengalami kesulitan, namun individu tersebut mengalami kesulitan dalam menguasai keterampilan belajar dan dalam melaksanakan tugas-tugas spesifik yang dibutuhkan dalam belajar seperti yang dilakukan dalam pendekatan dan metode pembelajaran konvensional.

Pada anak usia dini banyak sekali hal yang dipelajari, salah satunya adalah matematika. Matematika adalah suatu pengetahuan yang mampu mengembangkan kemampuan berpikir anak. Oleh sebab itu matematika dapat sebagai sarana untuk membangun kemampuan berpikir anak mulai dari usia dini, usia pendidikan kelas awal (pendidikan dasar), pendidikan menengah, pendidikan lajutan dan bahkan sampai mereka berada di bangku perkuliahan (Anwar, 2011).

Matematika sangat berguna sekali bagi anak usia dini untuk mengembangkan proses berpikirnya. Pada awal pendidikan matematika dapat diberikan mengenai pengenalan bilangan. Dapat diperdengarkan angka terlebih dahulu dengan menyebut satu, dua, dan seterusnya. Kemudian dapat diperlihatkan benda-benda dengan jumlah satu, dua, dan seterusnya. Bertambahnya kecerdasan dan umur seorang anak kemudian dapat diperkenalkan ke lambang bilangan.

Matematika merupakan cabang mata pelajaran yang cakupannya sangat luas dan bukan hanya bisa berhitung tetapi juga mencakup kompetensi yang 
menjadikan anak tersebut memahami dan mengerti tentang konsep matematika. Untuk pendidikan matematika dapat diberikan pada anak tingkat usia dini dengan metode learning by playing atau belajar sambil bermain, karena waktu bermain anak akan mendapat kesempatan bereksplorasi, bereksperimen dan dengan bebas mengekspresikan dirinya. Dengan bermain, tanpa sengaja anak akan memahami konsep-konsep matematika tertentu dan melihat adanya hubungan antara satu benda dan yang lainnya.

Jean Piaget (dalam Montessori, 2008) mengemukakan bahwa pelajaran membaca, menulis, dan berhitung secara tidak langsung dilarang untuk diperkenalkan pada anak-anak di bawah usia 7 tahun. Piaget beranggapan bahwa pada usia di bawah 7 tahun anak belum mencapai fase operasional konkret. Fase itu adalah fase, di mana anak-anak dianggap sudah bisa berpikir terstruktur. Sementara itu, kegiatan belajar calistung sendiri didefinisikan sebagai kegiatan yang memerlukan cara berpikir terstruktur, sehingga tidak cocok diajarkan kepada anak-anak TK yang masih berusia balita.

Montessori (2008) mengatakan bahwa pada usia 3-5 tahun, anak-anak dapat diajari menulis, membaca, dikte dengan belajar mengetik. Sambil belajar mengetik anak-anak belajar mengeja, menulis dan membaca. Ada suatu penelitian di Amerika yang menyimpulkan bahwa kenyataannya anakanak dapat belajar membaca sebelum usia 6 tahun. Hasil penelitian ini menunjukkan bahwa ada sekitar 2\% anak yang sudah belajar dan mampu membaca pada usia 3 tahun, $6 \%$ pada usia empat tahun, dan sekitar $20 \%$ pada usia 5 tahun. Bahkan terbukti bahwa pengalaman belajar di taman kanak-kanak dengan kemampuan membaca memadai akan sangat menunjang kemampuan belajar pada tahun-tahun berikutnya.

$$
\text { Teori }
$$

Dienes

(dalam

Novikasari,2016) merupakan salah satu jenis teori dalam belajar matematika dari matematikawan bernama Zoltan P. Dienes. Teori yang disampaikan Dienes bertumpu pada gagasan untuk menampilkan matematika dalam bentuk yang nyata dan menyenangkan bagi anak.

Dienes merumuskan 6 tahap berpikir matematika. Pertama adalah free play, anak diberi kebebasan untuk berinteraksi dengan lingkungan. Kebebasan dalam arti, kegiatan pembelajaran tahap awal dilakukan dengan memberi keleluasaan pada siswa mengenal, memperhatikan, mengidentifikasi segala bentuk permainan atau benda-benda konkrit yang disediakan 
dalam pembelajaran. Kedua games, pada tahap ini diberikan aturan sebelum dimulai dan beberapa kriteria yang harus dicapai sehingga dapat dikategorikan tujuan permainan tersebut tercapai. Generalisasi sebagai tahap ketiga anak mengenal pola, kesamaan, dan sifat umum pada model yang berbeda. Tahap keempat, representasi, anak diberikan kebebasan untuk mengekspresikan suatu metode atau cara untuk mewakili semua aktivitas games yang memiliki kesamaan struktur. Kebebasan berekspresi siswa dapat diwujudkan dalam bentuk visual maupun audio. Bentuk representasi visual misalkan adalah: gambar, bilangan atau angka, grafik. Tahap kelima simbolisasi, terjadi ketika anak menggunakan formula dan kata-kata untuk mendeskripsikan hubungan. Misalkan representasi simbol luas dan keliling. Terakhir tahap formalisasi, hubungan dan sifat gambar yang dikelompokkan, diurutkan, dan dikenal sebagai bagian dari struktur konsep matematika. Anak pada tahap awal belajar atau prasekolah sampai pada tahap simbolisasi untuk memaknai dunia dengan matematika.

Orang tua adalah guru pertama dan yang terpenting bagi anak. Dr. Burton White, pendiri dan direktur Proyek Prasekolah Harvard, mengatakan, "Nampaknya pengalaman pendidikan terbaik dalam tiga tahun pertama hidup seorang anak diperlukan apabila ia diharapkan akan mengembangkan seluruh potensinya." Selain itu, beberapa sosiolog dan pendidik, meyakinkan bahwa stimulasi seperti ini pada anak yang sangat mudah dapat mempercepat kemampuan belajarnya.( Chapman, dalam Rizkiyah, 2015).

Perkembangan awal intelektual anak terjadi di rumah. Lingkungan dan sikap yang menyenangkan menolong anak belajar di rumah. Kunci membuat anak belajar adalah orangtua, mulai dari bayi hingga selama masa pendidikan formalnya. Seperti halnya pendidikan informal yang berlangsung di dalam lingkungan keluarga, tempat seorang anak tumbuh dan berkembang akan sangat berpengaruh terhadap kepribadian seorang anak, terutama dari cara para orang tua mengasuh dan membesarkan anaknya. Karena itu pola asuh orang tua akan sangat menentukan perkembangan kognitif anak sekarang dan masa depan mereka. Kepribadian maupun tingkah laku seorang anak juga tidak akan terbentuk dengan sendirinya, melainkan dengan pengaruh lingkungannya. Peran orang tua juga dibutuhkan dalam hal memberikan semangat kepada anak untuk terus belajar tidak hanya dengan memberikan kebebasan, orang tua juga harus mampu 
mengontrol dan mendisiplinkan anak dalam hal belajar.

Apabila orang tua bekerja dengan menggunakan waktu yang biasa dimanfaatkan bersama anak, maka hal tersebut akan semakin membatasi waktu yang dapat digunakan bersama-sama dengan keluarga. Saat ini banyak para ibu memilih untuk bekerja, hal tersebut membuat pengasuhan akan sulit apabila hanya dilakukan oleh ibu saja, karena bekerja dan mengasuh anak bukan hal yang mudah bagi ibu yang bekerja. Meningkatnya jumlah istri yang bekerja juga menuntut ayah untuk lebih terlibat dalam pengasuhan. Keterlibatan ayah dalam pengasuhan sangat diperlukan bukan hanya karena sebagai pengganti ibu yang juga bekerja, namun karena anakanak memang sangat membutuhkan perhatian dari kedua orang tua di setiap tahap perkembangannya.

Pengasuhan bersama yang diterapkan dalam sebuah keluarga akan berdampak positif pada perkembangan anak, karena anak dapat merasakan kasih sayang dari kedua orang tuanya. Pengasuhan bersama dapat memberikan ketenangan dan kelangsungan hubungan kekeluargaan daripada pengasuhan secara mandiri.

Menurut Lestari (2012), anak pada umumnya tumbuh lebih baik bila diasuh oleh orang tua lengkap. Anak-anak dengan kedua orang tua yang tinggal serumah cenderung lebih baik secara emosi dan akademik. Anak-anak dapat memperoleh perhatian yang lebih dari kedua orang tua, misalnya dalam hal pendampingan, bantuan untuk menyelesaikan tugas sekolah, dan kualitas kebersamaan.

Berdasarkan hasil observasi dan laporan guru kelas yang dilakukan di kelas B TK Al-Zaitun Waru- Sidoarjo, ditemukan bahwa ada salah satu siswa yang masih belum mampu mengenal angka. Hal tersebut ditandai dengan observasi selama di sekolah dan informasi yang diberikan oleh guru serta orang tua. Berdasarkan observasi awal diketahui bahwa penyebab belum mampu mengenal angka kurangnya latihan dirumah karena siswa lebih banyak diasuh oleh neneknya dibanding oleh orang tuanya. Karena orang tua siswa tersebut bekerja terkadang hingga larut malam.

Salah satu upaya untuk membantu agar siswa dapat lebih mudah memahami tentang angka yaitu dengan memberikan pembelajaran melalui media kartu dan benda-benda yang menarik.

\section{METODE PENELITIAN}

Pendekatan yang digunakan dalam penelitian ini adalah pendekatan kualitatif. 
Pendekatan kualitatif sebagai prosedur penelitian yang menghasilkan data deskriptif berupa kata-kata tertulis atau lisan dalam bentuk tindakan kebijakan (Moeleong \& Lexy dalam Subandi, 2011). Metode penelitian yang terbentuk dari uraian kata-kata untuk dikumpulkan kemudian dilakukan analisis guna mendapatkan bahan penulisan yang otentik. Sehingga dapat diartikan bahwa pendekatan kualitatif adalah prosedur penelitian yang menghasilkan data kualitatif yang berupa kata-kata tertulis atau lisan dari narasumber dan perilaky yang telah diamati. Tipe penelitian ini merupakan studi kasus, sehingga penelitian dilakukan karena ketertarikan atau kepedulian pada suatu kasus khusus.

Untuk mendukung dan mendapatkan data dalam penelitian, peneliti menggunakan observasi, wawancara dan tes psikologi. Teknik observasi yang digunakan adalah observasi partisipan, peneliti turut ambil bagian dalam perikehidupan. Peneliti sebagai partisipan berarti dapat masuk berkomunikasi secara akrab sehingga dapat bertanya lebih detail dan rinci.

Alat observasi yang digunakan adalah anecdotal, pencatatan perilaku subjek dilakukan sesegera mungkin pada tingkah laku anak. Peneliti mencatat secara detail perilaku anak terjadi di sekolah dan di rumah. Hal ini bertujuan untuk mengetahui kegiatan subjek selama di sekolah serta relasi subjek dengan guru dan temannya. Sedangkan di rumah untuk mengetahui kegiatan dan perilaku subjek ketika di rumah serta kedekatan subjek dengan orang tau.

Teknik wawancara yang digunakan adalah semi-structured interviews, peneliti membuat daftar pertanyaan wawancara. Daftar pertanyaan tersebut dapat berbedabeda sesuai dengan kebutuhan peneliti atau subjek yang akan diteliti. Pertanyaan dapat diberikan dengan dua metode yaitu tersruktur dan semiterstruktur. Pada metode terstruktur bersifat tertutup, sedangkan metode semiterstruktur terdiri dari pertanyaan terbuka.

Tes psikologi hanya dapat diberikan tes BINET dan Bander Gestalt. Tes BINET diberikan untuk mengetahui kapasitas intelegensi anak, apakah sudah berkembang secara optimal sesuai dengan usianya, sedangkan Bander Gestalt diberikan untuk melihat kesiapan emosi belajar anak setara dengan usianya atau tidak, apakah sudah matang untuk masuk ketingkat pendidikan yang lebih tinggi. Subjek berjenis kelamin laki-laki berusia 5 tahun 7 bulan yang sedang berada di TK B.

Intervensi yang dilakukan dengan memberikan kegiatan belajar yang 
menyenangkan dengan menggunakan media kartu, puzzle atau bentuk nyata. Kemudian mengulang kembali pelajaran yang sudah diberikan. Intervensi juga diberikan kepada orang tua dan guru.

\section{HASIL DAN PEMBAHASAN}

Kapasitas intelegensi dalam kategori rata-rata, dengan aspek-aspek kemampuan yang sudah berkembang secara optimal dan ada yang belum berkembang secara optimal sesuai dengan usianya. Aspek-aspek kemampuan yang sudah berkembang secara optimal adalah aspek pengertian umum, pembendaharaan kata, kemampuan visual-motor, memorikonsentrasi, dan judgement \& reasoning. Hal ini menandakan bahwa subjek memahami hal-hal yang ada dilingkungannya. Namun pada aspek berhitung yang dimiliki oleh subjek masih butuh banyak latihan, sehingga banyak angka atau hal yang berhubungan dengan berhitung yang belum subjek kuasai, terkadang ia menjawab dengan respon yang lama. Sedangkan hasil dari Age Equivalenit kesiapan belajar emosi anak setara anak usia 5 tahun 2 bulan. Artinya subjek akan kesulitan dalam belajardan perlu penyesuaian lebih. Dapat dikatakan bahwa subjek belum matang dalam kesiapan belajar disekolah, sehingga dapat berpengaruh kepada prestasi akademiknya.

Hasil intervensi yang dilakukan kepada subjek yaitu melakukan kegiatan belajar mengenai aritmatika dasar, yaitu mengenal simbol angka 1-10 dengan media kartu, kemudian mengenal belasan, menghitung benda dan menghitung tanpa benda.

Selama 6 kali pertemuan subjek sudah dapat mengenal simbol angka 1-10, namun urutan angka 1-20 masih dalam tahap proses pembelajaran. Subjek masih sulit membedakan belasan dan puluhan, subjek cenderung mengatakan angka 12 yaitu "satu dua", sedangkan angka 20 "dua puluh belas". Sedangkan untuk menghitung benda subjke membutuhkan konsentrasi lebih agar dapat mengingat angka berapa yang sudah subjek hitung. Untuk menghitung tanpa benda, subjek juga harus mengetahui dan memahami konsep simbol angka, sehingga tidak ada yang terlewatkan.

Terdapat beberapa kendala dalam proses intervensi berlangsung yaitu terkadang subjek tidak didalam mood yang baik saat belajar, kemudian situasi rumah yang membuat subjek kurang fokus dalam belajar. 


\section{PENUTUP}

Subjek merupakan murid yang mengalami kesulitan belajar pada simbol angka dan hitungan. Proses dalam belajar dan menangkap informasi mengenai matematika dan hafalan dapat dikatakan lambat dibandingkan teman-temannya di sekolah. Saat ini masih berusaha mengingat simbol angka 1-20, sehingga guru dan orang tua sangat berusaha agar subjek dapat mengetahui simbol angka.

Berdasarkan asesmen yang dilakukan dengan metode observasi, wawancara, dan tes psikologi ditemukan bahwa subjek memiliki IQ dalam kategori rata-rata. Sehingga dapat dikatakan bahwa merupakan anak yang mampu dalam menangkap informasi-informasi baru. Aspek-aspek juga berkembang dengan optimal, meskipun dalam hal aspek aritmatika subjek masih butuh berlatih lagi. Selama memberikan intervensi di rumah subjek dan bertemu langsung dengan keluarga di rumahnya, tidak hanya dalam hal akdemik yang harus ditingkatkan oleh subjek, namun dalam aspek psikologisnya. subjek perlu mendapatkan kasih sayang yang lebih dari ibu dan ayah tirinya agar subjek tidak merasa dikucilkan didalam lingkungan sekolah atau sekitarnya.

Intervensi yang dilakukan adalah memberikan kegiatan belajar kepada subjek dengan menggunakan media, seperti kartu, atau mainan-mainan agar subjek dapat belajar dengan senang dan tidak merasa kesulitan. Selain itu juga memberikan psikoedukasi kepada orang tua khususnya ibu, mengenai apa yang dibutuhkan oleh subjek, bukan hanya mengenai akademik, namun diseimbangkan dengan perhatian dan kasih sayang yang lebih untuk subjek.

\section{DAFTAR PUSTAKA}

Adawiah, R. 2017. Pola Asuh Orang Tua

Dan Implikasinya Terhadap Pendidikan Anak (Studi Pada Masyarakat Dayak Di Kecamatan Halong Kabupaten Balangan). Jurnal Pendidikan Kewarganegaraan: Volume 7, Nomor 1, hal: 33-48.

Ahyani, L \& Raharjo, T. 2011. Identifikasi Kesulitan Belajar Pada Anak Pendidikan Usia Dini. Staf Pengajar Fakultas Psikologi. Universitas Muria, Kudus.

Anisa, Siti. 2005. Kontribusi Pola Asuh Orang tua terhadap Kemandirian Siswa Kelas II SMA Negeri 1 Balapulang Kabupaten Tegal Tahun Pelajaran 2004/2005. Skripsi. Universitas Negeri

Semarang.

Anwar, Rahmad. 2011. Analisis Kesulitan Belajar Matematika Pada Anak Usia Dini (Tingkat Pra Sekolah/Tk) Dan Alternatif Pemecahannya. GUIDENA, Vol.1, No.1, hal 63-72 
Lestari , S. 2012. Psikologi keluarga : penanaman nilai dan penanganan konflik dalam keluarga. Jakarta: kencana

Montessori, Maria. 2008. The Absorbent Mind (Pikiran yang Mudah Menyerap). Yogyakarta: Pustaka Pelajar

Najib, M. Agus, Azhar, Evi, S., dkk. 2005. Membangun Keluarga Sakinah Nan Maslahah: Panduan Bagi Keluarga Islam Modern. Yogyakarta : PSW UIN SUNAN KALIJAGA

Novikasari, Ifada. 2016. Matematika Dalam Program Pendidikan Anak Usia Dini (Paud). Bunayya: Jurnal Pendidikan Anak, Vol 2 (1), hal: 1-16.

Purnamasari, Aravita. Kamus Perkembangan Bayi \& Balita, Jakarta: Erlangga, 2005.

Rahman, U. 2009. Karakteristik Perkembangan Anak Usia Dini. Jurnal Lentera Pendidikan. Vol 12 (1). Hal: 46-57.

Rizkiyah, H. 2015. Peran Orang Tua Dalam Meningkatkan Minat Belajar Anak Usia Sekolah Dasar (6-12 Tahun) Di Dusun Kalikajang Kelurahan Gebang Sidoarjo. Jurnal Pendidikan Luar Sekolah.

Suarsini, Desy. 2013. Pola Asuh Orang Tua, Artikel (online)(http;//desysuar.blogspot.c om, diakses 10 Desember 2013)
Sumantri, M. 2014. Pertumbuhan Dan Perkembangan Anak. Universitas Terbuka 1. Hal: 1-52

Syah, Muhibbin. Psikologi Pendidikan dengan Pendekatan Baru, Bandung: Rosda, 2004.

Yus, Anita. Penilaian Perkembangan Belajar Anak Taman Kanak-kanak. Jakarta: Kencana, 2011. 